\title{
Factors affecting the number of debridements in Fournier's gangrene: our results in 36 cases
}

\author{
Fournier gangreninde debridman sayısını etkileyen faktörler: \\ 36 olguda sonuçlarımız
}

\section{Cemal GÖKTAŞ, ${ }^{1}$ Mehmet YILDIRIM, ${ }^{2}$ Rahim HORUZ, ${ }^{1}$ Gökhan FAYDACI, ${ }^{1}$ Oktay AKÇA, ${ }^{1}$ Cihangir Ali ÇETINEL ${ }^{1}$}

\section{BACKGROUND}

We aimed to evaluate the factors potentially affecting the number of surgical debridements in patients with Fournier's gangrene (FG) who underwent single or multiple operative sessions.

\section{METHODS}

We retrospectively reviewed the data of 36 patients with $\mathrm{FG}$. The patients were assigned to one of two groups according to the number of debridements (Group I: single session; Group II: $\geq 2$ sessions). Data of the patients (clinical and surgical data, lesion characteristics, FG severity index, and prognosis) were compared between the groups.

\section{RESULTS}

The mean age of the patients was 55.5 years, and all were male. Group I consisted of 21 patients and Group II of 15 patients. The mean number of debridements was 2.2 in Group II. Our overall mortality rate was 11\% (Group I: $4.8 \%$ vs Group II: $20 \%$; $=0.287)$. Diabetes was the most common coexistent pathology (44\%). Time to admission to the clinic, size of the lesions at admission, and FG Severity Index (FGSI) scores of the groups were similar. In Group II, FGSI scores were found increased before each of the repeated debridement sessions $(\mathrm{p}<0.05)$.

\section{CONCLUSION}

There was no difference in the clinical data of the patients who required single or multiple debridement sessions; however, FGSI may be useful in deciding repeated debridements, as it was found increased at each repeated session.

Key Words: Debridement; Fourniers gangrene; mortality; prognosis; surgical procedures.

\section{$\boldsymbol{A M A C}$}

Bu çalışmada, tek veya çok sayıda cerrahi debridman gereken Fournier gangreni (FG) hastaları karşılaştırıldı, debridman sayısını etkileyebilecek faktörler araştırıldı.

\section{GEREÇ VE YÖNTEM}

Fournier gangreni nedeniyle tedavi edilen 36 hastanın verileri geriye dönük olarak incelendi. Hastalar uygulanan debridman sayısına göre iki gruba ayrıldı (Grup I: tek seans; Grup II: $\geq 2$ seans). Hastalara ait veriler (klinik ve cerrahi veriler, lezyon özellikleri, FG şiddet indeksi, prognoz verileri) gruplar arasında karşılaştırıldı.

\section{BULGULAR}

Hastaların ortalama yaşı 55,5 idi ve hepsi erkekti. Grup I'de 21, Grup II'de 15 hasta incelendi. Grup II'de ortalama debridman sayıs 2,2 idi. Genel mortalite oranı \%11 olarak saptand 1 (Grup I'de \%4,8, Grup II'de \%20; p=0,287). Diyabet en sık karşılaşılan komorbidite idi (\%44). Hastaneye başvuruya kadar geçen süre, başvuru sırasında lezyonun boyutu ve FG şiddet indeksi açısından gruplar arasında fark tespit edilmedi. Grup II'de FG şiddet indeksi skorunun tekrarlanan her operasyon öncesinde anlamlı derecede artış gösterdiği saptand $1(\mathrm{p}<0,05)$.

\section{SONUÇ}

Her ne kadar tek veya çok sayıda debridman uygulanan hastalar arasında debridman sayısını etkileyebilecek anlamlı fark saptanmamışsa da; FG şiddet indeksi, tekrarlanan her debridmanda arttığı tespit edildiği için, ilave debridmanlara karar vermede yardımcı olabilir.

Anahtar Sözcükler: Debridman; Fournier gangreni; mortalite; prognoz; cerrahi prosedürler. 
Fournier's gangrene (FG) is a rare necrotizing infection that affects the perineal and genital area, and is an emergent disease that still carries a high risk of mortality. ${ }^{[1]}$ The principle of the treatment is achieving an urgent debridement combined with an appropriate wide-spectrum antibiotherapy. Since FG has a progressive nature, repeated debridements may be required in some cases.

In this study, we compared the clinical findings and treatment outcomes of cases that underwent single or multiple surgical debridement sessions because of FG, with an aim to evaluate the potential association between the number of debridements and prognosis, in order to test a hypothesis that the prognosis might be worse in patients requiring additional debridements.

\section{MATERIALS AND METHODS}

We retrospectively reviewed the data of 36 patients with the diagnosis of FG treated in our clinic from 2004 to 2010 . The diagnosis was primarily based on physical examination; data of complete blood count and serum levels of creatinine, sodium, potassium, and bicarbonate were noted. Infected tissues of the lesions were sampled during debridement and were examined microbiologically. In all cases, applied antibiotherapy and clinical outcomes were evaluated.

The patients were allocated into one of two groups according to the number of debridements: Group I consisted of cases with single debridement, while Group II consisted of the cases that underwent two or more debridement sessions. Patient data including demographics, characteristics of the lesion, factors in the etiology, coexistent pathologies, scores of Fournier's Gangrene Severity Index (FGSI) before each debridement, localization of the primary lesion, lesion size on presentation, duration between the appearance of primary lesion and admission, results of microbiological cultures and antibiogram, and antibiotherapy schedules applied were compared between the groups. Cases resulting in death were particularly evaluated. Statistical evaluation was performed by use of chisquare, Kruskal-Wallis and Mann-Whitney U tests.

\section{RESULTS}

Group I consisted of 21 patients and Group II of 15 patients. Since 11 of 15 patients in Group II had 2 debridement sessions and 4 patients had 3 debridement sessions, the total number of debridement procedures was 55 . The mean number of debridements per patient was 1.5.

The mean ages of patients overall, in Group I and in Group II were comparable, as 55.5 (22-80), 54.8 (22$80)$ and $56.5(31-73)$ years, respectively $(\mathrm{p}=0.936)$. All of the cases were male. While the primary lesion was classified as of urogenital or perineal origin in 53\% and $9 \%$ of the cases, respectively, it was not possible to specify an etiologic origin in $38 \%$ of the cases.

In 23 cases (64\%), there was at least one coexisting pathology, and diabetes mellitus (DM) was the most common, at a ratio of $44 \%(n=16)$. While DM was the only documented comorbidity in 11 patients, it coexisted with at least one other systemic pathology, such as chronic renal disease, hypertension, coronary artery disease, or chronic obstructive pulmonary disease, in the remaining 5. Of these 5 cases, 1 patient also had prostate cancer, and another had paraplegia as an underlying pathology. The rates of coexistent disease in Groups I and II were $52.2 \%$ and $80 \%$, respectively, and the difference was not statistically significant $(\mathrm{p}=0.484)$ (Table 1).

The mean duration between the appearance of the initial lesion and admission to the clinic was detected as relatively long, at 5.2 days, and was similar when compared between the groups $(p=0.441)$ (Table 1). The mean size of lesions at the first physical examination was similar in Group I and Group II $\left(26.6 \mathrm{~cm}^{2}\right.$ vs. $37.8 \mathrm{~cm}^{2}$, respectively; $\mathrm{p}=0.172$ ) (Table 1 ).

Overall FGSI score of the cases was 2.4 on admission. There was no significant difference in FGSI scores between groups (2.1 and 2.8 in Group I and Group II, respectively; $\mathrm{p}=0.149$ ). On the other hand, the mean FGSI scores were found as 2.4, 2.9 and 3.7 before the first, and if performed, the second and third debridement sessions, respectively. The difference was statistically significant ( $\mathrm{p}=0.0001$, for all groups). The FGSI of the 4 patients with mortality was a mean of 4.7 .

Regarding the initial localization of the lesion during the first physical examination, it was seen that the scrotal area had been involved in all cases either as the only affected site or with neighboring skin. While a single session of surgical debridement was adequate in $69 \%$ of the cases with isolated scrotal lesion, the rate of one successful debridement was $52 \%$ in patients in whom neighboring tissues had been involved in addition to the scrotum. Although the number of required sessions appeared to be higher in larger lesions involving adjacent tissues along with the scrotum, this difference was not found as significant $(\mathrm{p}=0.484)$ (Table 1$)$.

Once FG had been diagnosed by physical examination, wide-spectrum antibiotherapy with cefazolin $2 \mathrm{x}$ $1 \mathrm{~g} /$ day, gentamicin $1 \times 160 \mathrm{mg} /$ day and metronidazole $2 \times 500 \mathrm{mg}$ /day was started in all of the patients. When microbiological reports were evaluated, it was seen that culture was negative in $8(22 \%)$ of the patients, while a single bacterial agent was reported in 24 $(67 \%)$ and mixed infection in $4(11 \%)$ of the patients. The most commonly reported bacterial agent was Escherichia coli (in 15 of 19 single agent infections, and in all of 4 mixed infections). Microbiological 
Table 1. Summary of the demographic, clinical and microbiological data of the patients

\begin{tabular}{|c|c|c|c|c|}
\hline & Group I & Group II & Overall & $\mathrm{p}$ \\
\hline Patients (n) & 21 & 15 & 36 & \\
\hline Debridement (n) & 21 & 34 & 55 & \\
\hline Age (years) & 54.8 & 56.5 & $55.5 \pm 15.1$ & 0.936 \\
\hline \multicolumn{5}{|l|}{ Etiology $(n)$} \\
\hline \multicolumn{5}{|l|}{ Urogenital origin } \\
\hline Scrotal skin infection & 9 & 4 & 13 & \\
\hline Orchitis and/or scrotal abscess & 2 & 4 & 6 & \\
\hline Perineal origin & 0 & 3 & 3 & \\
\hline Unknown & 10 & 4 & 14 & \\
\hline Underlying coexistent disease (n) & $11(52 \%)$ & $12(80 \%)$ & $23(64 \%)$ & 0.484 \\
\hline Size of the lesion in initial examination $\left(\mathrm{cm}^{2}\right)$ & $26.6 \pm 20.6(6-96)$ & $37.8 \pm 27.4(12-100)$ & $31.2(6-100)$ & 0.172 \\
\hline Time to the admission $(\mathrm{day} \pm \mathrm{SD}$, range) & $5.5 \pm 2.5(2-9)$ & $4.9 \pm 2.5(3-14)$ & $5.2 \pm 2.6(2-14)$ & 0.441 \\
\hline \multicolumn{5}{|l|}{ Microbiological results (n) } \\
\hline Single agent & 12 & 12 & 24 & \\
\hline E. coli & 7 & 8 & 15 & \\
\hline MRSA & 3 & 1 & 4 & \\
\hline Pseudomonas & 1 & 0 & 1 & \\
\hline Enterococcus & 1 & 2 & 3 & \\
\hline Streptococcus & 0 & 1 & 1 & \\
\hline Mixed & 3 & 1 & 4 & \\
\hline Culture-negative & 6 & 2 & 8 & \\
\hline Change in antibiotherapy regimen (n) & 6 & 7 & 13 & 0.310 \\
\hline \multicolumn{5}{|l|}{ FGSI } \\
\hline Before first debridement $(\mathrm{n}=36)$ & $2.1 \pm 1.3$ & $2.8 \pm 1.8$ & $2.4 \pm 1.7$ & 0.149 \\
\hline Before second debridement $(\mathrm{n}=15)$ & & $2.9 \pm 1.9$ & & \\
\hline Before third debridement $(\mathrm{n}=4)$ & & $3.7 \pm 2.1$ & & \\
\hline Mortality (n) & $1(4.8 \%)$ & $3(20.0 \%)$ & $4(11.1 \%)$ & 0.287 \\
\hline \multicolumn{5}{|l|}{ Localization during admission (n) } \\
\hline Penoscrotal & 3 & 5 & 8 & \\
\hline Scrotal & 9 & 4 & 13 & \\
\hline Perineoscrotal & 6 & 3 & 9 & \\
\hline Perineopenoscrotal & 3 & 3 & 6 & \\
\hline
\end{tabular}

n: Number; FGSI: Fournier's Gangrene Severity Index; MRSA: Methicillin-resistant Staphylococcus aureus.

results are shown in Table 1 . The antibiotic regimen had to be changed according to the results of bacterial culture in 13 patients ( 6 in Group I, 7 in Group II; $\mathrm{p}=0.310)$.

Data regarding duration of hospitalization was significantly different between the groups, at 18.6 and 33.5 days in patients in Group I and Group II, respectively $(\mathrm{p}=0001)$. Our overall mortality rate was $11 \%$ $(\mathrm{n}=4)$ (1 patient in Group I vs 3 patients in Group II; $p=0.287$ ). It is notable that there was at least one coexistent underlying pathology in all of our mortal cases, and the mean FGSI score of these patients (4.7) was apparently higher than that of the others. Data of the cases resulting in mortality are summarized in Table 2.

\section{DISCUSSION}

Necrotizing fasciitis is a rare and potentially fatal infectious condition characterized by acute onset and high risk of morbidity and mortality, and FG is a spe- cific form of this disease that affects primarily the skin and subcutaneous tissues of the external genitalia and perineum..$^{[1]}$

It is generally characterized by a polymicrobial infection that results in obliterative endarteritis, ischemia, and consequently, necrosis of the skin and adjacent tissues. ${ }^{[2,3]}$ Genitourinary infections, trauma, anorectal abscess, immunosuppression, DM, renal or hepatic dysfunction, and alcoholism are reported among the predisposing factors in the literature. ${ }^{[4]}$

Since it was first defined, FG remains among the most important emergent diseases in the practice of urologists with its high mortality. ${ }^{[5]}$ With its rapidly progressive nature, necrotizing fasciitis carries the risk of invading unexpectedly large areas of the skin if not treated appropriately and, most importantly, on time. In addition to the systemic effects of the infection itself, exotoxins released from the affected necrotic tissue may result in disturbed hemostasis, septic/toxic 
Table 2. Data of the cases resulting in mortality

\begin{tabular}{|c|c|c|c|}
\hline & Group I & Group II & Overall \\
\hline Patient (n) & 1 & 3 & 4 \\
\hline Sessions (n) & 1 & 7 & 8 \\
\hline Age (years) & 72 & 52 & 57 \\
\hline \multicolumn{4}{|l|}{ Etiology } \\
\hline Perineal abscess & 0 & 2 & 2 \\
\hline Scrotal abscess & 1 & 1 & 2 \\
\hline Coexistent disease $(\mathrm{n}, \%)$ & $1(100 \%)$ & $3(100 \%)$ & $4(100 \%)$ \\
\hline Prostate carcinoma (n) & 1 & & \\
\hline $\mathrm{DM}+\mathrm{CRF}(\mathrm{n})$ & & 1 & \\
\hline $\mathrm{DM}(\mathrm{n})$ & & 2 & \\
\hline Size of the lesion at admission (mm) & 30 & 36.6 & 35 \\
\hline Time to the admission (days) & 3 & 4.8 & 4.2 \\
\hline Initial FGSI & 4.0 & 5.0 & 4.7 \\
\hline \multicolumn{4}{|l|}{ Microbiologic culture } \\
\hline E. coli & 1 & - & 1 \\
\hline Streptococcus & - & 1 & 1 \\
\hline E. coli + Enterococcus & - & 1 & 1 \\
\hline Negative & - & 1 & 1 \\
\hline \multicolumn{4}{|l|}{ Localization of the lesion } \\
\hline Scrotal & 1 & - & 1 \\
\hline Penoscrotal & - & 1 & 1 \\
\hline Perineoscrotal & - & 1 & 1 \\
\hline Perineopenoscrotal & - & 1 & 1 \\
\hline
\end{tabular}

n: Number; DM: Diabetes mellitus; CRF: Chronic renal failure; FGSI: Fournier's Gangrene Severity Index.

shock, and eventually death in some of the cases. ${ }^{[6]}$ The rate of progression of the lesion in necrotizing fasciitis was reported in the literature as being as fast as 2 $\mathrm{mm}$ per hour. ${ }^{[7]}$ It may result from various etiological origins; however, its course may be more mortal when developed from an anorectal origin than with urogenital origin. ${ }^{[8-11]}$ Our series did not include any patient with anorectal origin.

While early recognition of the lesion is one of the major determinants of the outcome of the disease, surgical treatment along with medical measures are the cornerstones of therapy. In order to be able to prevent its rapid progression, aggressive surgical debridement, local wound care and broad-spectrum systemic antibiotherapy should be performed without delay. Since the visible borders of the gangrene may often be misleading, an efficient debridement should involve removal of $1-2 \mathrm{~cm}$ of healthy-appearing tissues that surround the lesion after clearance of all necrotic tissues of the skin and subcutaneous layers.

Reappearance of the necrosis indicates that the initial debridement was insufficient and a repeat is necessary. In most of the studies, the mean number of debridements per patient was reported as higher than one. ${ }^{[10,12,13]}$ Similarly, repeated debridements were required in $42 \%$ of our patients.

In a study of Laor et al., ${ }^{[14]}$ it was reported that the number of debridements is not associated with the patient's outcome. In comparison, Chawla et al. ${ }^{[13]} \mathrm{re-}$ ported a higher number of debridements in the nonsurvival group of their study, although they concluded that this has no predictive value regarding the prognosis. In that study, they reported the mean number of debridements as 2.2 for 14 patients who survived and as 5.2 for 5 cases resulting in mortality. They attributed this finding as due to the fact that sicker patients require more debridements. ${ }^{[13]}$

In our study, 3 of 4 deaths were in the group of cases with repeated debridement sessions. In other words, while the mortality rate in patients treated with a single session of debridement was $4.8 \%$, it was found as high as $20 \%$ in the group of patients who required multiple debridements. Although not statistically significant, this difference may support the suggestion that the mortality increases as the number of debridements increases in FG. Some authors have associated the prognosis of FG with the age and sex of the patients, and reported an increased risk in female and elderly patients. ${ }^{[15,16]}$ However, we did not detect any direct relation between age and the number of debridements, and we had no female patients in our series.

Although the initial localization of the lesion may be helpful in determining the etiological origin, FG generally presents with lesions larger than the original one as they progressively involve the surrounding ar- 
eas of the initial lesion. When we evaluated the origins of the lesions in our patients, the chance of surgical cure by single debridement appeared to be higher in the patients in whom the initial lesion had been in the scrotum; however, this finding was not statistically significant. In one study, Tuncel et al. ${ }^{[17]}$ reported that the extent of disease has a predictive value on prognosis. In our patients, the mean size of the lesion at admission was higher in Group II than in Group I. However, we could not detect any significant association between the size of the lesion and the number of debridements in our series.

Diabetes mellitus (DM) is generally observed as a comorbid disease in patients with FG, and it was the most common comorbidity in our study. DM has been reported as a risk factor and prognostic factor of FG in the literature. ${ }^{[18-20]}$ In one study, Nisbet et al. ${ }^{[18]}$ showed that the number of debridements was not different between the diabetic and non-diabetic FG patients. Similarly, we found that presence of comorbidities did not affect the number of debridements required $(\mathrm{p}<0.05)$.

Fournier's Gangrene Severity Index (FGSI) has been a widely used instrument by urologists since it was first described by Laor ${ }^{[14]}$ In spite of the presence of some studies objecting to the use of the FGSI score as a predictive factor, ${ }^{[17]}$ a significant relationship between the FGSI score and prognosis in FG was reported in several studies. ${ }^{[10,21,22]}$ Ersay et al. ${ }^{[10]}$ reported a significant correlation between FGSI score and duration of hospitalization and number of debridements. In our study, although no association was detected between the FGSI score of the initial examination and number of debridements, we found that the FGSI showed a tendency to increase in Group II patients in the preoperative evaluations of each repeated debridement. This result may mean that the patients with increasing FGSI are at risk of a progression that will potentially require repeated debridements. Although the mean interval between the debridement sessions was calculated as 4.3 days in our study, we do not have enough data to comment on the exact frequency of assessment of the laboratory components of FGSI.

Early diagnosis is an important prognostic factor in FG..$^{[9,12]}$ Akgün et al. ${ }^{[9]}$ reported that the duration between the first signs of the disease and admission to the hospital was longer in the cases resulting in mortality. However, regarding the admission or diagnosis time, we could not detect any difference in the cases in whom multiple debridements were required or in fatal cases when compared with the others.

Since FG is an infectious disease, antibiotics are also of key importance in the treatment in addition to the surgery. Among the first measures, a broad-spectrum antibiotic regimen with Gram-negative, Gram- positive and anaerobic coverage should be started immediately. In accordance with the literature, ${ }^{[6]}$ the most frequent microbial agent in our study was also $E$. coli. Changes in the initial broad-spectrum antibiotherapy regimens according to the results of bacterial culture tests showed no association with the number of debridements.

Although we were not able to show a significant relationship between the number of debridements and the prognosis of FG, and there was no statistical difference between the groups of patients with single or multiple debridements in our study, we believe that a potential relation between debridement number and prognosis should be tested in larger studies. On the other hand, the direct correlation we detected between the number of debridements and the increasing FGSI in per-patient analysis may be interpreted as indicating that FGSI, in the case of its increase, may be helpful as an adjunct to other clinical parameters when deciding a repeated debridement session, by alerting physicians about the prognosis.

In conclusion, since there was no difference in the clinical data of the patients with FG who required single or multiple debridement sessions, we could not identify a predictive tool for repeated surgical interventions in the treatment of FG. FGSI may be useful in deciding repeated debridements, as it was found increased at every repeated session; however, its prognostic and predictive value should be tested in larger studies.

\section{REFERENCES}

1. Sorensen MD, Krieger JN, Rivara FP, Klein MB, Wessells H. Fournier's gangrene: management and mortality predictors in a population based study. J Urol 2009;182:2742-7.

2. Mehl AA, Nogueira Filho DC, Mantovani LM, Grippa MM, Berger R, Krauss D, et al. Management of Fournier's gangrene: experience of a university hospital of Curitiba. Rev Col Bras Cir 2010;37:435-41.

3. Vick R, Carson CC 3rd. Fournier's disease. Urol Clin North Am 1999;26:841-9.

4. Smith GL, Bunker CB, Dinneen MD. Fournier's gangrene. Br J Urol 1998;81:347-55.

5. Basoglu M, Ozbey I, Atamanalp SS, Yildirgan MI, Aydinli B, Polat $\mathrm{O}$, et al. Management of Fournier's gangrene: review of 45 cases. Surg Today 2007;37:558-63.

6. Martínez-Rodríguez R, Ponce de León J, Caparrós J, Villavicencio H. Fournier's gangrene: a monographic urology center experience with twenty patients. Urol Int 2009;83:323-8.

7. Atakan IH, Kaplan M, Kaya E, Aktoz T, Inci O. A lifethreatening infection: Fournier's gangrene. Int Urol Nephrol 2002;34:387-92.

8. Enriquez JM, Moreno S, Devesa M, Morales V, Platas A, Vicente E. Fournier's syndrome of urogenital and anorectal origin. A retrospective, comparative study. Dis Colon Rectum 1987;30:33-7.

9. Akgün Y, Yilmaz G. Factors affecting mortality in Fournier's gangrene. Ulus Travma Acil Cerrahi Derg 2005;11:49-57. 
10. Ersay A, Yilmaz G, Akgun Y, Celik Y. Factors affecting mortality of Fournier's gangrene: review of 70 patients. ANZ J Surg 2007;77:43-8.

11. Eke N. Fournier's gangrene: a review of 1726 cases. Br J Surg 2000;87:718-28.

12. Norton KS, Johnson LW, Perry T, Perry KH, Sehon JK, Zibari GB. Management of Fournier's gangrene: an eleven year retrospective analysis of early recognition, diagnosis, and treatment. Am Surg 2002;68:709-13.

13. Chawla SN, Gallop C, Mydlo JH. Fournier's gangrene: an analysis of repeated surgical debridement. Eur Urol 2003;43:572-5.

14. Laor E, Palmer LS, Tolia BM, Reid RE, Winter HI. Outcome prediction in patients with Fournier's gangrene. J Urol 1995; 154:89-92.

15. Czymek R, Frank P, Limmer S, Schmidt A, Jungbluth T, Roblick U, et al. Fournier's gangrene: is the female gender a risk factor? Langenbecks Arch Surg 2010;395:173-80.

16. Simsek Celik A, Erdem H, Guzey D, Celebi F, Birol S, Erozgen F, et al. Fournier's gangrene: series of twenty patients. Eur Surg Res 2011;46:82-6.
17. Tuncel A, Aydin O, Tekdogan U, Nalcacioglu V, Capar Y, Atan A. Fournier's gangrene: Three years of experience with 20 patients and validity of the Fournier's Gangrene Severity Index Score. Eur Urol 2006;50:838-43.

18. Nisbet AA, Thompson IM. Impact of diabetes mellitus on the presentation and outcomes of Fournier's gangrene. Urology 2002;60:775-9.

19. Malik AM, Sheikh S, Pathan R, Khan A, Sheikh U. The spectrum of presentation and management of Fournier's gangrene--an experience of 73 cases. J Pak Med Assoc 2010;60:617-9.

20. Korkut M, Içöz G, Dayangaç M, Akgün E, Yeniay L, Erdoğan $\mathrm{O}$, et al. Outcome analysis in patients with Fournier's gangrene: report of 45 cases. Dis Colon Rectum 2003;46:64952.

21. Lin E, Yang S, Chiu AW, Chow YC, Chen M, Lin WC, et al. Is Fournier's gangrene severity index useful for predicting outcome of Fournier's gangrene? Urol Int 2005;75:119-22.

22. Yeniyol CO, Suelozgen T, Arslan M, Ayder AR. Fournier's gangrene: experience with 25 patients and use of Fournier's gangrene severity index score. Urology 2004;64:218-22. 